Global Nest: the Int. J. Vol 1, No 1, pp 47-53, 1999

Copyright@ 1998 GLOBAL NEST

Printed in Greece. All rights reserved

\title{
AMMONIA AND PHOSPHORUS REMOVAL IN MUNICIPAL WASTEWATER TREATMENT PLANT WITH EXTENDED AERATION
}

\author{
E. SOTIRAKOU \\ G. KLADITIS \\ N. DIAMANTIS \\ H. GRIGOROPOULOU *
}

\section{ABSTRACT}

Samples were taken from Metamorphosis/Attica combined treatment plant for municipal wastewater and septage, which treats about $12000 \mathrm{~m}^{3} \mathrm{~d}^{-1}$ of municipal wastewater and $8000 \mathrm{~m}^{3} \mathrm{~d}^{-1}$ of septage, and analyzed for solids, COD, ammonia, nitrate, orthophosphate, polyphosphate and total phosphorus. Ammonia is almost completely eliminated within the plant. Orthophosphates show a removal of about $28 \%$, while total phosphorus is removed by about $15 \%$. The mean value of the ratio (phosphorus eliminated)/(COD eliminated) in $\mathrm{mg} \mathrm{g}^{-1}$ is 8 . Assuming suspended-growth nitrification and denitrification kinetics as proposed in literature, the percentage of nitrifiers in the activated sludge population is estimated at $1.1 \%$. Assuming that phosphorus removal in the aeration tank is proportional to cell formation, which in turn is proportional to substrate elimination, the phosphorus content of the activated sludge is estimated at $0.031 \mathrm{gP}(\mathrm{gVSS})^{-1}$.

KEY WORDS: ammonia removal, phosphorus removal, activated sludge plant, extended aeration, municipal wastewater.

\section{INTRODUCTION}

Nitrogen appears in wastewater as ammonia, nitrite, nitrate and organic nitrogen. Organic nitrogen is decomposed to ammonia, which in turn on one hand is assimilated to bacterial cells, leading thus to net growth, on the other hand is oxidized to nitrite and nitrate. In a second step, nitrate is converted to gaseous nitrogen and is removed from the wastewater. Denitrification is known to proceed as conversion of nitrates to nitrites and subsequent conversion of nitrites to nitric oxide, nitrous oxide and nitrogen gas.
Nitrifying organisms are present in almost all aerobic biological treatment processes, but usually their numbers are limited, depending on the mean cell residence time (because of the threshold effect) and on the $\mathrm{BOD}_{5} / \mathrm{N}$ ratio. In most conventional activated-sludge processes, with a $\mathrm{BOD}_{5} / \mathrm{N}$ ratio of 3 , the fraction of nitrifying organisms is estimated to be considerably less than 0.083 , while for $\mathrm{BOD}_{5} / \mathrm{N}$ ratios of 5 to 9 , the estimated percentage is between 0.054 and 0.029 (Metcalf and Eddy, 1991).

Suspended-growth nitrification and denitri- 
fication processes are generally adopted to obey Monod-type kinetics, with the maximum nitrification rate depending on temperature $\left(\mathrm{T},{ }^{\circ} \mathrm{C}\right), \mathrm{pH}$ and dissolved oxygen (DO, $\mathrm{mg} \mathrm{l}^{-1}$ ). Representative kinetic coefficients $\left(\mu_{\mathrm{m}}\right.$ in $\mathrm{d}^{-1}, \mathrm{~K}_{\mathrm{S}}$ in $\mathrm{mg} \mathrm{l}^{-1}, \mathrm{Y}$ in $\mathrm{mgVSS}^{-1}$, $\mathrm{k}_{\mathrm{d}}$ in $\mathrm{d}^{-1}$ ) are given in the literature (Metcalf and Eddy, 1991).

Phosphorus appears in wastewater as orthophosphate, polyphosphate and organically bound phosphorus, the last two components accounting usually for up to 70 percent of the influent phosphorus. Microbes utilize phosphorus during cell synthesis and energy transport. As a result, 10 to 30 percent of the influent phosphorus is removed during traditional mechanical/biological treatment (Wenzel and Ekama, 1997; Mulder and Rensink, 1987; Metcalf and Eddy, 1991; Henze, 1996; Sedlak, 1991). When enhanced phosphorus removal is desired, the process is modified, so that the sludge is exposed to both anaerobic and aerobic conditions. Then certain microorganisms, capable of storing phosphorus (in the form of polyphosphates), metabolize it for energy production and cell synthesis, resulting in the removal of phosphorus from the system through the waste activated sludge.

The Metamorphosis/Attica combined treatment plant was designed for full treatment of $24000 \mathrm{~m}^{3} \mathrm{~d}^{-1}$ of raw and highly dilute septage whose design characteristics were (in $\left.\mathrm{mg} \mathrm{l}^{-1}\right): \mathrm{BOD}_{5}=1200, \mathrm{COD}=$ $4000, \mathrm{SS}=2300$, total Kjeldahl $\mathrm{N}=320$ of which $\mathrm{NH}_{4}{ }^{+}=290$ (Degremont, 1991) and of $20000 \mathrm{~m}^{3} \mathrm{~d}^{-1}$ of municipal wastewater (65000 p.e.). Estimating one population equivalent (p.e.) at $70 \mathrm{~g} \mathrm{BOD} \mathrm{d}^{-1}$, with aeration basin volume at $21000 \mathrm{~m}^{3}$, the design value for BOD/MLSS.d was 0.47 . The plant was, thus, designed to work as a conventional aeration system. It provides grit and grease removal, primary settling, activated sludge, clarification and chlorination units for wastewater and anaerobic treatment, thickening and dewatering for the sludge produced. Municipal wastewater and septage follow separate treatment lines until the biological treatment unit. However today, with the loads treated (i.e. BOD/ MLSS.d is about 0.2), the plant operates at extended aeration conditions.

Actually the plant treats about $12000 \mathrm{~m}^{3} \mathrm{~d}^{-1}$ of municipal wastewater and $8000 \mathrm{~m}^{3} \mathrm{~d}^{-1}$ of septage and unexpectedly introduced industrial wastes. The $\mathrm{BOD}_{5} / \mathrm{N}$ ratio of septage was found to have roughly a value of 10 (mean of values throughout a year) (Andreadakis, 1989). A value of about 11 is reported in literature (Metcalf and Eddy, 1991) while 10 is a typical value proposed by EPA (1984). At the treatment plant of Kavala municipal wastewater (in Northern Greece) a value of 5 was measured (with a design value of 6) (Liakos and Stamou, 1991). Based on the estimations mentioned above for the percentage of the nitrifying microorganisms, the actual fraction is expected to be around 0.04 .

The present study was undertaken to evaluate the extent to which ammonia and phosphorus are removed in the Metamorphosis/Attica combined treatment plant.

\section{MATERIALS AND METHODS}

Two-hour composite samples were taken daily from Metamorphosis/Attica combined treatment plant. These were withdrawn at the inlet of the activated sludge basin (two sampling points, one for municipal wastewater and one for septage respectively) and at the outlet of the secondary clarifier. Analyses were performed promptly after sampling.

Total nonfiltrable solids (TNFS) were determined as the retained material on a Whatman 3 qualitative filter after filtration of a well-mixed sample. Total suspended solids (TSS) were determined after centrifugation of a well-mixed sample at $8000 \mathrm{rpm}$ for $15 \mathrm{~min}$. Total volatile suspended solids (VSS) were determined by igniting the samples at $550 \pm 50^{\circ} \mathrm{C}$. Chemical oxygen demand (COD) was determined by the dichromate reflux method. Ammonia nitrogen $\left(\mathrm{N}-\mathrm{NH}_{4}\right)$ was determined by the direct nesslerization method. Addition of $\mathrm{ZnSO}_{4}$ was not necessary for the outlet samples, as they were clear and colorless. Nitrate nitrogen $\left(\mathrm{N}-\mathrm{NO}_{3}\right)$ content of the outlet samples was determined by the UV-spectrophotometric screening method. Orthopho-sphates (ortho-P) were determined by the vana-domolybdophosphoric acid colorimetric method. Polyphosphates were indirectly determined by the acid hydrolysisvanadomolybdate method and calculated as the difference between acid-hydrolyzable (hydr.-P) and orthophosphate phosphorus. All analyses were performed to filtered samples according to APHA 15th ed. 1980. Total phosphorus (tot.P) was determined according to a digestion method proposed by Hach 
Co. (reagents : mixture of sulfuric acid $97 \%$ and hydrogen peroxide 30\%, 2,4-dinitrophenol indicator, potassium hydroxide) (Hach Co., 1987), followed by orthophosphate determination as above. A Perkin-Elmer spectrophotometer model 550S was used.

Sampling was performed over a period of two months during winter. This time interval was estimated to be adequate, as no major unusual events or accidental overflows were observed during the sampling period.

\section{RESULTS AND DISCUSSION}

The daily values of ammonia and nitrate nitrogen, phosphates and total phosphorus $\left(\mathrm{mg} \mathrm{l}^{-1}\right)$ are presented in Figs. 1-2. A relatively stable pattern can be seen to prevail, except for the total $\mathrm{P}$ values, which, because of the introduction of some industrial loads, known to happen eventually, were abnormally high. These high values are not considered when calculating typical values and estimating microbial population characteristics.

Average values as well as the standard deviation
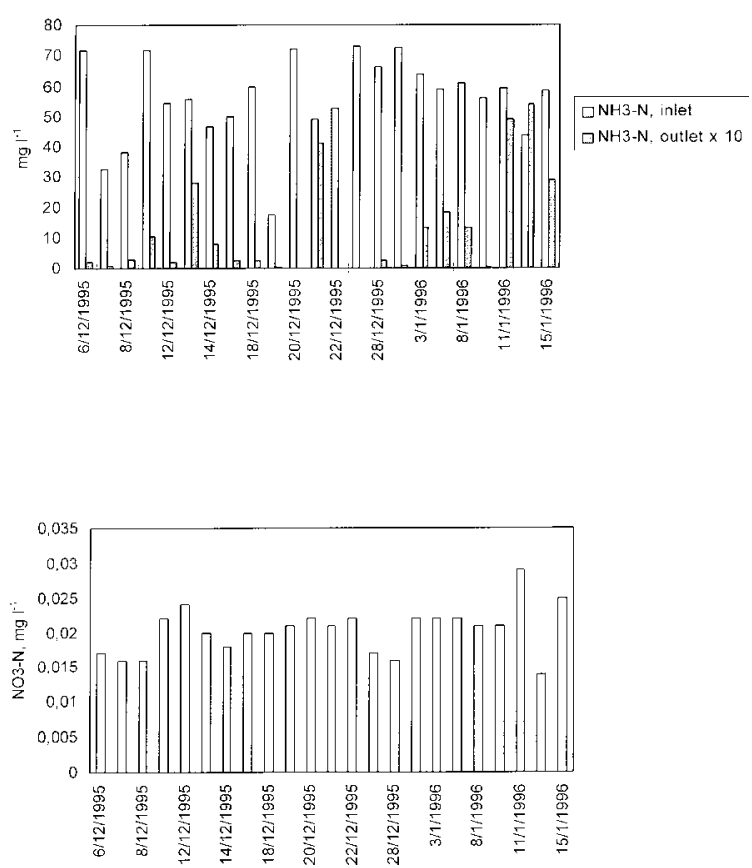

Figure 1. Amounts of $\mathrm{NH}_{4}-\mathrm{N}$ in the inlet and outlet and of $\mathrm{NO}_{3}-\mathrm{N}$ in the outlet of the aeration basin at Metamorphosis / Attica
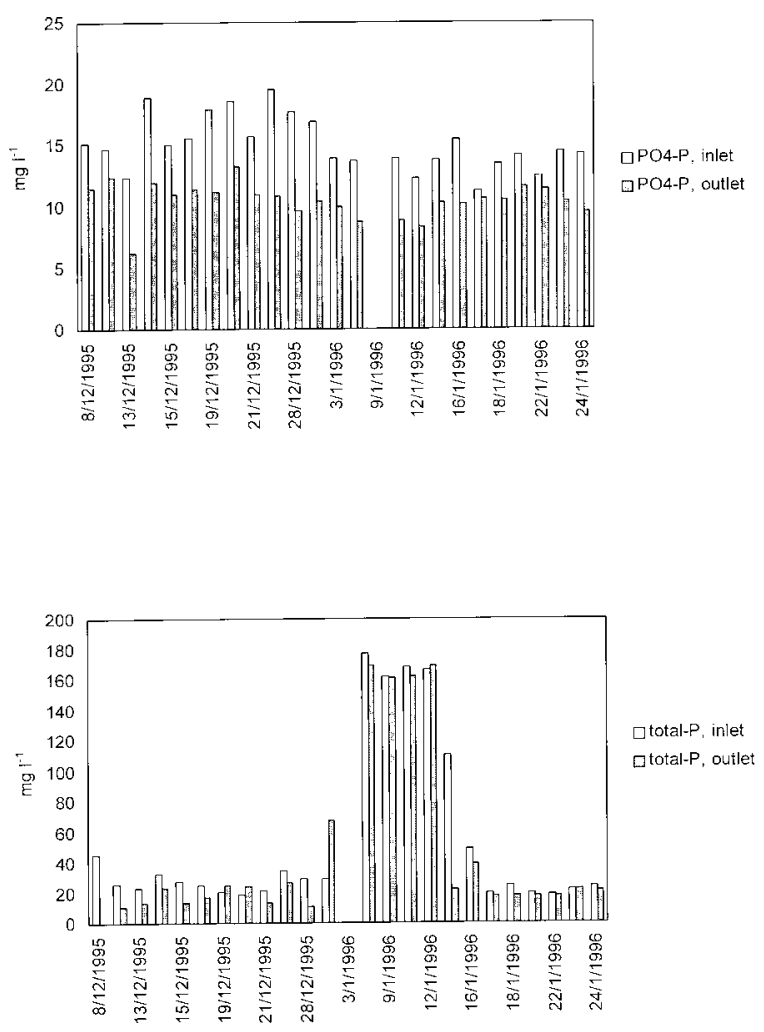

Figure 2. Amount of $\mathrm{PO}_{4}-\mathrm{P}$ and of total $\mathrm{P}$ in the inlet and outlet of the aeration basin at Metamorphosis/ Attica.

and the range of the measured parameters are reported in Table 1.

As can be seen from Table 1, inlet values show a wide variation, which seems to be reduced at the outlet.

Ammonia is almost completely (98\%) eliminated within the plant. Orthophosphates removal varies between 14 and $58 \%$ (average 28\%), while total phosphorus is removed by 11 to $48 \%$ (average 15\%). These findings are in good agreement with removals reported in literature: Henze (1991) and Metcalf and Eddy (1991) report values of $10-25 \%$ for phosphorus removal during secondary treatment. On the other hand, $0.5-1 \mathrm{mg}$ $\mathrm{N}-\mathrm{NH}_{4}(\mathrm{gMVLSS} \mathrm{h})^{-1}$ can be assimilated in extended aeration systems (CEMAGREF, 1990, Eckenfelder and Argaman, 1991). In our case, ammonia assimilation is calculated to be around

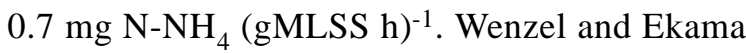
(1997) estimate the phosphorus content of sludge to $2-4 \%$. In our case, with sludge production estimated at 0.8 times $\mathrm{BOD}_{\text {inlet }}$, phosphorus removal 
Table 1. Inlet and outlet values of soluble COD, total nonfiltrable solids, total suspended solids, ortho-, hydrolyzableand total $\mathrm{P}$ and $\mathrm{NH}_{4}{ }^{+}$- and $\mathrm{NO}_{3}{ }^{-}-\mathrm{N}\left(\right.$ in $\left.\mathrm{mg} \mathrm{l}^{-1}\right)$ at the combined septage - wastewater plant at Metamorphosis, Attica (Average values. Standard deviation in brackets. Range in parentheses).

\begin{tabular}{|c|c|c|c|c|c|c|c|c|c|c|c|}
\hline & flow, $\mathrm{m}^{3} \mathrm{~d}^{-1}$ & $\mathrm{pH}$ & TNFS & TSS & VSS/TSS & COD & ortho-P & hydr.-P & tot.-P & $\mathrm{N}-\mathrm{NH}_{4}$ & $\mathrm{~N}-\mathrm{NO}_{3}$ \\
\hline $\begin{array}{l}\text { Inlet, } \\
\text { municipal }\end{array}$ & $\begin{array}{c}11700 \\
{[1540]} \\
(9000-17000)\end{array}$ & $\begin{array}{c}7.52 \\
{[0.18]} \\
(7.2-7.8)\end{array}$ & $\begin{array}{c}47 \\
{[38]} \\
(10-100)\end{array}$ & $\begin{array}{c}129 \\
{[59]} \\
(71-208)\end{array}$ & $\begin{array}{c}0.72 \\
(0.70-0.75)\end{array}$ & $\begin{array}{c}390 \\
{[79]} \\
(225-90)\end{array}$ & $\begin{array}{c}22.9 \\
{[3.3]} \\
(9.4-30)\end{array}$ & $\begin{array}{c}20.2 \\
{[6.8]} \\
(16-47)\end{array}$ & $\begin{array}{c}30.6^{*} \\
{[9.7]} \\
(19-56)\end{array}$ & $\begin{array}{c}49.2 \\
{[12]} \\
(32-64)\end{array}$ & - \\
\hline $\begin{array}{l}\text { Inlet, } \\
\text { septage }\end{array}$ & $\begin{array}{c}7500 \\
{[1060]} \\
(4700-8700)\end{array}$ & $\begin{array}{c}8.32 \\
{[1.14]} \\
(6.7-12.4)\end{array}$ & $\begin{array}{c}314 \\
{[300]} \\
(30-1630)\end{array}$ & $\begin{array}{c}452 \\
{[508]} \\
(156-1658)\end{array}$ & $\begin{array}{c}0.47 \\
(0.4-0.5)\end{array}$ & $\begin{array}{c}754 \\
{[538]} \\
(256-2540)\end{array}$ & $\begin{array}{c}1.7 \\
{[1.5]} \\
(0.21-6.7)\end{array}$ & $\begin{array}{c}2.0 \\
{[2.8]} \\
(0.4-13)\end{array}$ & $\begin{array}{c}20.3 \\
{[13.2]} \\
(3.2-42)\end{array}$ & $\begin{array}{c}67.9 \\
{[14]} \\
(45-93)\end{array}$ & - \\
\hline Outlet & & $\begin{array}{c}7.70 \\
{[0.12]} \\
(7.5-7.9)\end{array}$ & $\begin{array}{c}25 \\
{[19]} \\
(3-70)\end{array}$ & $\begin{array}{c}32 \\
{[26]} \\
(3-72)\end{array}$ & & $\begin{array}{c}43 \\
{[18]} \\
(10-74)\end{array}$ & $\begin{array}{c}10.5 \\
{[1.5]} \\
(3.1-13)\end{array}$ & $\begin{array}{c}10.9 \\
{[2.1]} \\
(6.2-13)\end{array}$ & $\begin{array}{c}22.7 \\
{[13.1]} \\
(11-39)\end{array}$ & $\begin{array}{c}0.94 \\
{[0.8]} \\
(0.2-5.4)\end{array}$ & $\begin{array}{c}0.021 \\
{[0.004]} \\
(0.014-0.029)\end{array}$ \\
\hline
\end{tabular}

* the values obtained from 6/1 until 12/1/96 have been omitted, as abnormally high.

is estimated at about $100 \mathrm{~kg}$ total- $\mathrm{P} \mathrm{d}^{-1}$, with average actual values of $80 \mathrm{~kg}$ total- $\mathrm{P} \mathrm{d}^{-1}$.

The fact that orthophosphates removal is higher than that of total phosphorus, however strange may it seem, is probably linked to the poor orthophosphate content of the septage and to the nature of the industrial wastes, accidentally introduced to the treatment plant.

Table 2. Operational data for the combined septage wastewater plant at Metamorphosis, Attica, obtained by EYDAP.

\begin{tabular}{|c|c|}
\hline Characteristic & Value \\
\hline municipal wastewater flow, $\mathrm{m}^{3} \mathrm{~d}^{-1}$ & 12000 \\
\hline septage flow, $\mathrm{m}^{3} \mathrm{~d}^{-1}$ & 8000 \\
\hline hydraulic retention time, $\mathrm{h}$ & $27-28$ \\
\hline mean cell-residence time, $\mathrm{d}$ & 13 \\
\hline temperature, ${ }^{\circ} \mathrm{C}$ & 13 \\
\hline dissolved oxygen, $\mathrm{mg} \mathrm{l}^{-1}$ & 1.5 \\
\hline MLSS, $\mathrm{mg} \mathrm{l}^{-1}$ & 3000 \\
\hline inlet $\mathrm{BOD}_{5} / \mathrm{COD}$ & 0.58 \\
\hline outlet $\mathrm{BOD}_{5} / \mathrm{COD}$ & 0.32 \\
\hline
\end{tabular}

In Table 2, data for the combined septagewastewater plant at Metamorphosis/Attica are reported. According to the data of Tables 1 and 2, a mean ratio $\mathrm{P}_{\text {eliminated }} / \mathrm{COD}_{\text {eliminated }}\left(\mathrm{mg} \mathrm{g}^{-1}\right)$ value of 8 is calculated. Mulder (1987) attributes a value of 6 to the same ratio for a conventional plug-flow fullscale plant train operating at $8-16^{\circ} \mathrm{C}, 2.6 \mathrm{~h}$ retention time, with $16 \% \mathrm{P}$ removal, having a capacity of
40000 p.e., where about $75 \%$ of the influent is domestic.

Ammonia utilization rates $\left[\mathrm{U}_{\mathrm{N}}, \mathrm{gN}^{-\mathrm{NH}^{+}}{ }_{4}\right.$ (gMLSS d $)^{-1}$ ] can be calculated by the following equation:

$\left(\mathrm{Q}_{1} \mathrm{~N}_{01}+\mathrm{Q}_{2} \mathrm{~N}_{02}\right)-\left(\mathrm{Q}_{1}+\mathrm{Q}_{2}\right) \mathrm{N}=\mathrm{U}_{\mathrm{N}} \mathrm{XV}$

where,

Q the volumetric feed rates, $\left(\mathrm{m}^{3} \mathrm{~d}^{-1}\right)$,

$\mathrm{X}$ the mixed liquor suspended solids content of the aeration tank (MLSS, $\mathrm{g} \mathrm{m}^{-3}$ )

$\mathrm{N}$ the appropriate ammonia concentrations $\left(\mathrm{g} \mathrm{m}^{-3}\right)$.

Indices 0 are attributed to inlet values, while indices 1 and 2 to municipal wastewater and septage, respectively. The basin volume $\mathrm{V}$ is $21000 \mathrm{~m}^{3}$.

Daily values of ammonia utilization rates are presented in Fig. 3.

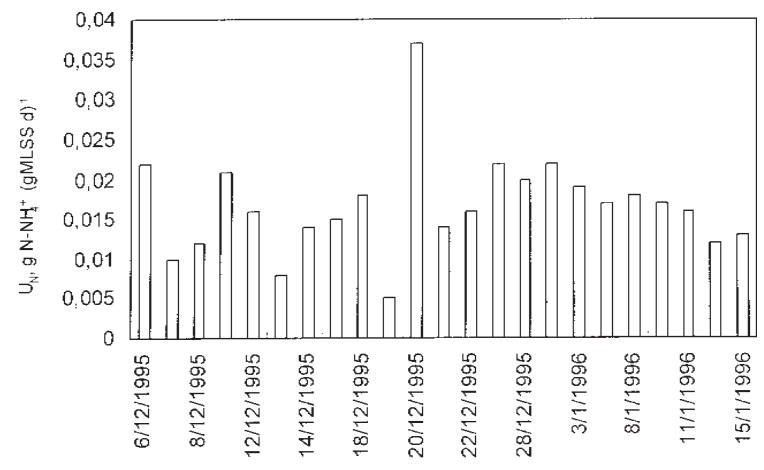

Figure 3. Daily values of $\mathrm{N}-\mathrm{NH}_{4}$ uptake rates in the aeration basin at Metamorphosis, Attica. 
Kinetics and kinetic coefficients proposed by Metcalf and Eddy (1991) are assumed. The pertinent equations are:

$$
\begin{aligned}
& \mathrm{U}_{\mathrm{N}}=\mathrm{k} \cdot \mathrm{N} /\left(\mathrm{K}_{\mathrm{N}}+\mathrm{N}\right) \\
& \mathrm{K}_{\mathrm{N}}=10(0.061 \mathrm{~T}-1.158) \\
& \mathrm{k}=\mu_{\mathrm{m}}^{\prime} / \mathrm{Y} \\
& \text { [1-0.833(7.2-pH)] }
\end{aligned}
$$

where,

$\mathrm{k}$ maximum rate of substrate utilization, time ${ }^{-1}$

$\mathrm{N} \quad \mathrm{N}-\mathrm{NH}_{4}{ }^{+}$concentration, $\mathrm{mg} \mathrm{l}^{-1}$

$\mathrm{K}_{\mathrm{N}}$ half-velocity constant, $\mathrm{mg} \mathrm{l}^{-1}$

$\mu_{\mathrm{m}}^{\prime}$ specific growth rate, time ${ }^{-1}$

$\mu_{\mathrm{m}}$ maximum specific growth rate, time ${ }^{-1}$

$\mathrm{K}_{\mathrm{O} 2}$ equal to 1.3

$\mathrm{Y}$ maximum yield coefficient, equal to 0.2 .

From the data of Tables 1 and 2, the effective specific growth rate $\mu_{\mathrm{m}}^{\prime}$ (relative to ammonia removal) of the biomass in the activated sludge basin can be estimated. Comparison of the values obtained with values predicted from literature for nitrifying biomass (Metcalf and Eddy, 1991), can give an estimation of the percentage of nitrifiers in the activated sludge population.

Following the above mentioned procedure and based on the data presented in Tables 1 and 2, the percentage of nitrifiers in the activated sludge population is estimated between 0.4 and $2.4 \%$, with a typical value of $1.1 \%$.

Daily estimated values of the percentage of nitrifiers in the activated sludge population are presented in Fig. 4.

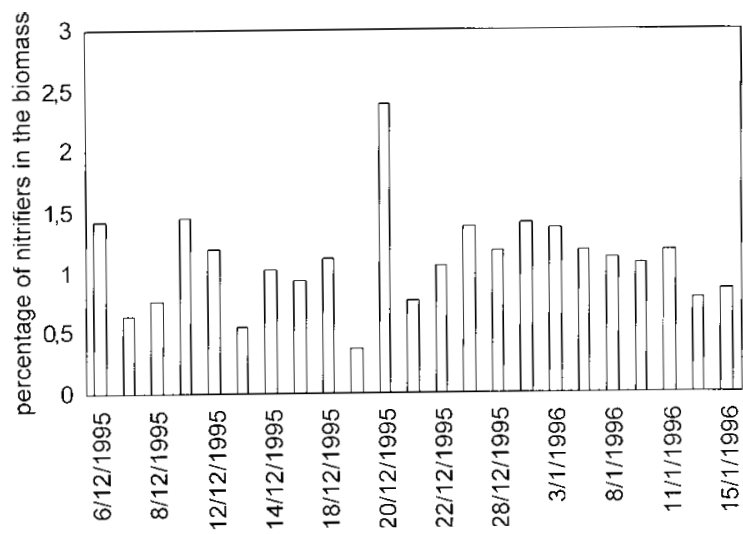

Figure 4. Daily estimated values of nitrifiers' percentage in the aeration basin.
Phosphorus uptake rate $\left(\mathrm{U}_{\mathrm{P}}, \mathrm{mg} \mathrm{P}^{-1} \mathrm{~d}^{-1}\right)$ can be calculated from the following equation:

$$
\left(\mathrm{Q}_{1} \mathrm{P}_{01}+\mathrm{Q}_{2} \mathrm{P}_{02}\right)-\left(\mathrm{Q}_{1}+\mathrm{Q}_{2}\right) \mathrm{P}=\mathrm{U}_{\mathrm{P}} \mathrm{V}
$$

with $\mathrm{P}$ the appropriate total phosphorus concentrations $\left(\mathrm{mg} \mathrm{l}^{-1}\right)$.

Daily values of phosphorus uptake rates are presented in Fig. 5.

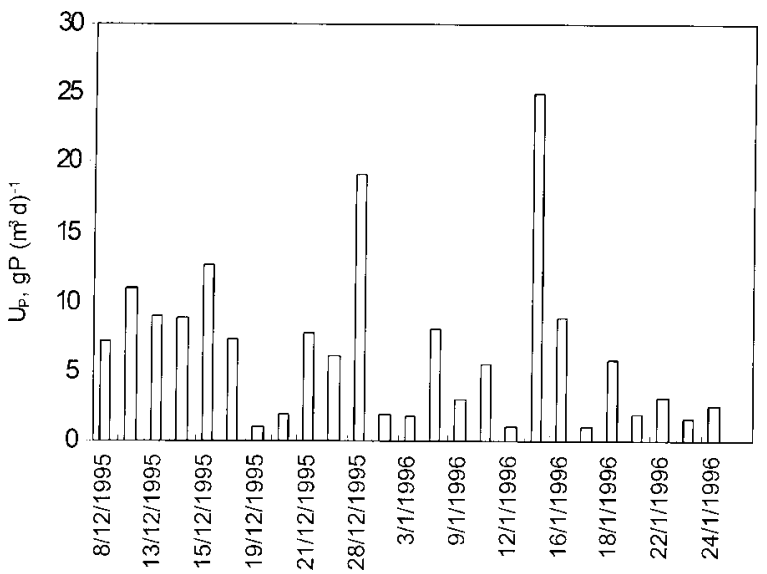

Figure 5. Daily values of total-P uptake rates in the aeration basin at Metamorphosis / Attica.

Assuming that phosphorus uptake $\left(\mathrm{U}_{\mathrm{p}}\right)$ in the aerated tank is proportional to cell formation $\left(\mathrm{r}_{\mathrm{X}}, \mathrm{mg} \mathrm{VSS}^{-1}{ }^{-1}\right.$. $\left.\mathrm{d}^{-1}\right)$ we have:

$$
\mathrm{U}_{\mathrm{P}}=-\mathrm{a}_{\mathrm{P}}\left(\mathrm{r}_{\mathrm{X}}\right)=\mathrm{a}_{\mathrm{P}} \mathrm{a}\left(-\mathrm{r}_{\mathrm{S}}\right)
$$

where,

$r_{X} \quad$ is proportional to substrate elimination $\left(-r_{S}\right.$, $\left.\mathrm{mg} \mathrm{BOD} \mathrm{l}^{-1} \mathrm{~d}^{-1}\right)$ and calculated from a mass balance equation similar to equation (6),

$\mathrm{a}_{\mathrm{P}} \quad$ is the phosphorus content of the activated sludge [mgP $\left(\mathrm{mgVSS}^{-1}\right]$

a

is the maximum yield coefficient [mg VSS $\left.\left(\mathrm{mgBOD}_{5}\right)^{-1}\right]$, taking values between 0.4 and 0.8 , with a typical value of 0.6 (Metcalf and Eddy, 1991).

Using the data presented in Tables 1 and 2 and following the procedure described above for the estimation of nitrifiers, a value of $\mathrm{a}_{\mathrm{p}}$ (the phosphorus content of the activated sludge) between 0.0082 and $0.066 \mathrm{gP}(\mathrm{gVSS})^{-1}$, with an average value of 0.031 , is estimated.

Daily estimated values of the phosphorus content of the activated sludge are presented in Fig. 6 . 


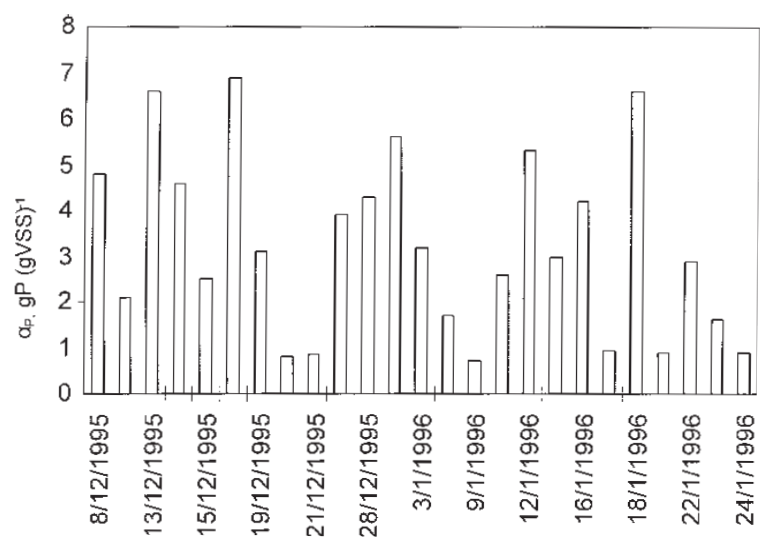

Figure 6. Daily estimated values of phosphorus content of the sludge in the aeration basin.

\section{CONCLUSIONS}

Although the Metamorphosis/Attica combined treatment plant for municipal wastewater and septage was designed as a conventional activated sludge plant, it is actually operating as a treatment plant with extended aeration. Removal rates are, however, quite high; suspended solids are removed at a rate of $87 \%$ that is within the range expected (85 to $90 \%$ ). COD removal has a value of $92 \%$, a value, which is considered to be quite satisfactory.

Ammonia is almost completely eliminated within the plant, due to extensive aeration of the wastewater. Orthophosphates and total phosphorus show removal values of about $28 \%$ and $15 \%$, respectively. Neither during the design nor at the initial stages of plant operation was the fate of nitrogen and phosphorus taken into consideration. The fact, however, of the successful operation of the modified plant, as indicated by the measured COD and suspended solids removals, is further supported by the, well within the expected range, removals of ammonia and phosphorus.

Assuming suspended-growth nitrification and denitrification kinetics proposed in literature, the percentage of nitrifiers in the activated sludge population is estimated between 0.4 and $2.4 \%$. Assuming that phosphorus removal in a conventionally aerated tank is proportional to cell formation, which in turn is proportional to substrate elimination, the phosphorus content of the activated sludge is estimated between 0.0082 and $0.066 \mathrm{gP}(\mathrm{gVSS})^{-1}$.

\section{Acknowledgments}

The authors wish to thank EYDAP (the Water Authority for the Athens greater area) for providing us with permission of entry into the treatment plant. They also thank the staff members of the Metamorphosis / Attica combined treatment plant, especially $\mathrm{Mr} \mathrm{H}$. Thodos, for kindly sharing the technical data of Table 2 and providing liquid samples, as well as for their pertinent advices during this study.

\section{REFERENCES}

Andreadakis, A. (1989). Combined treatment of domestic sewage and septage. Proc. 1st Congr. Env. Sci. Technol., Mytilini, Greece, 302-317.

APHA-AWWA-WPCF (1980). Standard Methods for the Examination of Water and Wastewater. 15th edition, APHA, Washington, USA.

CEMAGREF (1990) Elimination de l' azote dans les stations d' epuration biologique des petites collectivites, Documentation Technique FNDAE, Paris, France.

Degremont (1991). Water Treatment Handbook, 6th edition, 1278-1280. Lavoisier Publishing, Paris, France.

Eckenfelder, W.W. and Argaman, Y. (1991). Principles of biological and physical/chemical nitrogen removal. In Phosphorus and nitrogen removal from municipal wastewater. Principles and practice, $2^{\text {nd }}$ edition, 3-41. Sedlak, R. (Editor), Lewis Publishers, USA.

EPA (1984). Septage Treatment and Disposal. Cincinatti, Ohio.

Hach Co. (1987). Digestion and Analysis of Wastewater, Liquids, Solids and Sludges. 1st edition, Hach Company, Loveland, USA.

Henze M. (1996). Biological phosphorus removal from wastewater: processes and technology. Water Quality International, July / August 1996, 32-36.

Liakos S., Stamou A. (1991). Kavala's wastewater treatment plant with extended aeration. Proc. 2nd Congr. Env. Sci. Technol., Mytilini, Greece, 83-92.

Metcalf and Eddy (1991). Wastewater Engineering. Treatment, Disposal, Reuse. 3rd edition, McGraw-Hill Int. Ed., Singapore. 
Mulder J.W., Rensink J.H. (1987). Introduction of biological phosphorus removal to an activated sludge plant with practical limitations, Biological Phosphate Removal from Wastewaters. In Advances in Water Pollution Control, R.Ramadori Ed., Pergamon, England, 213-223.

Wenzel, MC.. Ekama, GA. (1997). Principles in the design of single sludge activated sludge systems for biological removal of carbon, nitrogen and phosphorus. In La dephosphatation des eaux usees, Ed. CEBEDOC, Belgium, 13-26. 